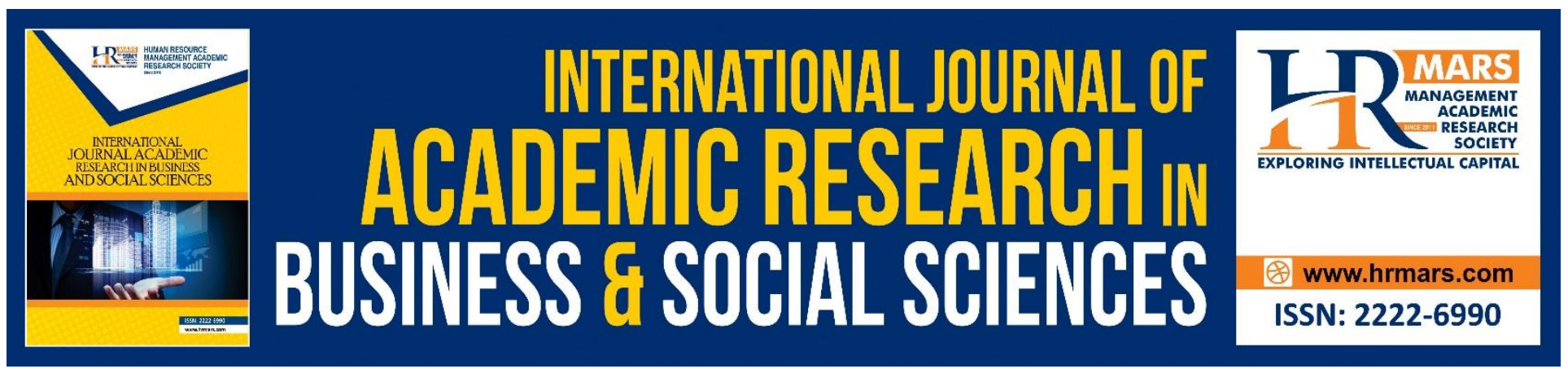

\title{
Technical Efficiency of the Pineapple Smallholders at Johor: Data Envelopment Analysis
}

Siti Nur Syuhada Mohamed Rahim, Nasuddin Othman

To Link this Article: http://dx.doi.org/10.6007/IJARBSS/v9-i3/5740

DOI: $10.6007 /$ IJARBSS/v9-i3/5740

Received: 25 Jan 2019, Revised: 25 Feb 2019, Accepted: 21 March 2019

Published Online: 26 March 2019

In-Text Citation: (Rahim \& Othman, 2019)

To Cite this Article: Rahim, S. N. S. M., \& Othman, N. (2019). Technical Efficiency of the Pineapple Smallholders at Johor: Data Envelopment Analysis. International Journal of Academic Research in Business and Social Sciences, 9(3), 746-755.

Copyright: (C) 2019 The Author(s)

Published by Human Resource Management Academic Research Society (www.hrmars.com)

This article is published under the Creative Commons Attribution (CC BY 4.0) license. Anyone may reproduce, distribute, translate and create derivative works of this article (for both commercial and non-commercial purposes), subject to full attribution to the original publication and authors. The full terms of this license may be seen

at: http://creativecommons.org/licences/by/4.0/legalcode

Vol. 9, No. 3, 2019, Pg. 746 - 755

http://hrmars.com/index.php/pages/detail/IJARBSS

JOURNAL HOMEPAGE

Full Terms \& Conditions of access and use can be found at http://hrmars.com/index.php/pages/detail/publication-ethics 


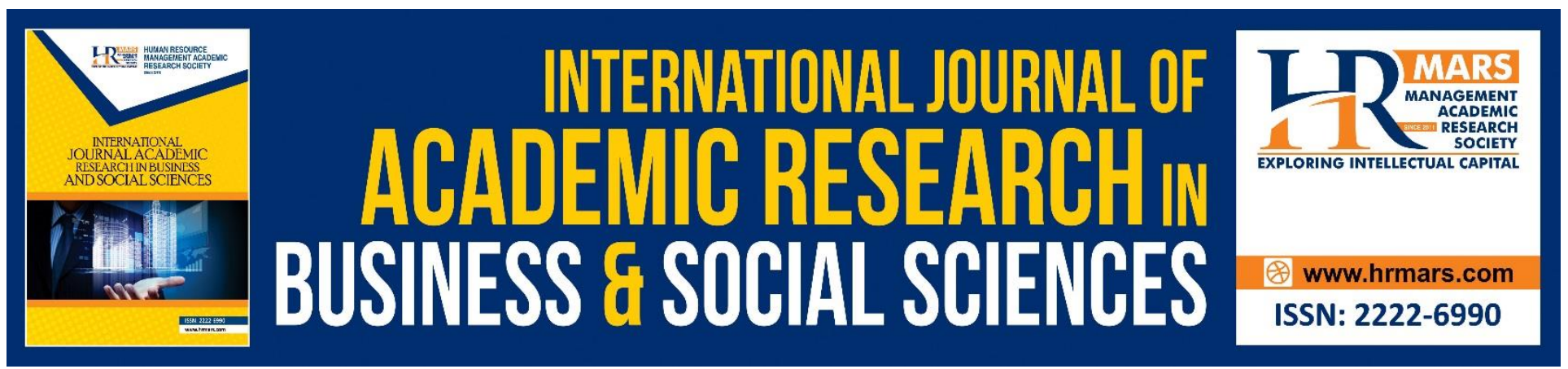

\title{
Technical Efficiency of the Pineapple Smallholders at Johor: Data Envelopment Analysis
}

\author{
Siti Nur Syuhada Mohamed Rahim ${ }^{1}$, Nasuddin Othman² \\ ${ }^{1}$ Faculty of Plantation and Agrotechnology, Universiti Teknologi MARA, 40450 Shah Alam, Malaysia \\ ${ }^{2}$ Faculty of Plantation and Agrotechnology, Universiti Teknologi MARA, 40450 Shah Alam, Malaysia
}

\section{ABSTRACT}

Background: Johor is the main pineapple producer in Malaysia. However, this state is still facing the issue of low productivity where the productivity level is $24 \mathrm{Mt} / \mathrm{ha}$ compared to the national target which is at $40 \mathrm{Mt} / \mathrm{ha}$ (MPIB, 2015). The low productivity is caused by the existence of inefficient smallholders operating below the economics of scale. Objective: Thus, there is an urgent need to study the productivity status by investigating their technical efficiency levels. The data collected from 88 respondents were analyzed using Data Envelopment Analysis (DEA), focusing on Variable Return to Scale (VRS) with the assumption of output-oriented. Results: The findings suggested that smallholders are inefficient with VRS Technical Efficiency (TE) score ranging from 0.50 to 1.00. Variables that are affecting the smallholder's technical efficiency are age, education level, land size, labor utilization, seeds density, chemical application and fertilizer while the farming experience had a negative effect on the technical efficiency. Conclusion: These findings could be used as a baseline data by the relevant parties or agencies involve in improving the pineapple farmers' productivity and technical efficiency.

Keywords: Pineapple farmers, Productivity, Small-scale farmers, Variable Return to Scale

\section{INTRODUCTION}

Pineapple (Ananas Comosus) production in Malaysia is still very low compared to her neighboring countries such as Thailand, Philippines, Indonesia and Vietnam. Malaysia failed to be the world's main pineapple producer due to the low production although it was dominating the market 4 decades ago. The main issue in Malaysia pineapple industry is the input and resources management, where we failed to fully utilize all the resources available, thus impacting the productivity (Nik Ismail et al., 2010). In 2014, the pineapple national productivity target is at 40 metric tonnes per hectare, but the actual figures were only 24 metric tonnes per hectare (MPIB, 2015).Thus, there exists a huge gap of the actual and potential yield. The low national pineapple productivity is caused by the smallholders that work in a less efficient manner and below economics of scale. Johor has the highest number of smallholders but the state productivity recorded only at $27.78 \mathrm{MT} / \mathrm{Ha}$ in 2014 compared to Negeri Sembilan at $43.54 \mathrm{Mt} / \mathrm{Ha}$ and Selangor at $40.57 \mathrm{Mt} / \mathrm{Ha}$ (MOA, 2015). Thus, there is a need to study 
the productivity level of the smallholders at Johor by focusing on their technical efficiency issue. The objective of this study is to investigate the technical efficiency level achieved by the pineapple smallholders at Johor and its determinant.

\section{METHODOLOGY}

The Study Area and Data Collection

Study was carried out using structured questionnaires to 88 respondents from 4 regions at Johor. The districts at Johor were divided into four regions namely region I, region II, region III and region IV. The multi- stage technique was used in this research. First, the population was stratified according to the region; secondly the proportionate random sampling with no replacement was used. Sample was randomly picked based on the size of the region.

\section{The Research Framework}

Technical efficiency (TE) refers to the ability of a firm to attain the maximum potential output from a specified combination of inputs and technology (Ogundari and Ojo, 2007). In examining the TE level achieved by the farmers, Data Envelopment Analysis (DEA) recommended by Charnes et al. (1984) was utilized. Besides, this study adopted the theory of production that served as a pillar in order to determine the relationship between input factors and dependent variable. The input factors namely; land, labour, seed density, fertilizer, hormone and chemical were specified as the independent variables while technical efficiency, which was measured in percentage, was specified as the dependent variable. Farming experience, level of education attained by the farmers, farm record management, training program and extension agent contact were selected as the demographic variables in the study area.

Two ways to measure efficiency which are parametric or nonparametric techniques. Farrell (1957) stated that there are two pertinent concepts that must take into account which is input-oriented or output-oriented in order to measure the efficiency. Under input - oriented measure, the firm intends to minimize the input quantity while maintaining the output level. Whereas output - oriented measure is focused on expanding the quantity of output in production without altering the quantity level of input. In this study, DEA approach that estimates the TE and output- oriented concepts will be employed. This research is concentrated to maximize the pineapple production of small scale farmers by utilizing the existing inputs that they applied. This non- parametric approach which using the linear programming will calculate rather than estimating the efficiency. The score for DEA is ranged between 0 to 1.0, based on Charnes et al. (1984). Farmers are indicated as the Decision Making Unit (DMU) who controls the input and output of farm. This approach enables to calculate the input and output associated to each DMU which help to solve the efficiency problems individually.

Technical Efficiency under Variable Return to Scale (VRS)

When the farm is at optimum scale level, it assumed that it is under the constant return to scale (DEA-CRS) and therefore it is not necessary to change any in the scale of production because there is no more gain in the efficiency level. However in the real circumstances, it is impossible for a farm to perform technical efficiency due to some disturbances such as weather factors, government 
intrusion, the lack of technologies, source of fund and imperfect competition. Thus it is reasonable to measure the TE using variable return to scale (DEA-VRS) which explained that a firm might be in the position of increasing return to scale or the opposite. The DEA-VRS model is also known as BCC model (named after Banker, Charnes, and Cooper) which was introduced by Charnes et al (1984). It is the extension of DEA-CRS model and a new constraint $\left(I 1^{\prime} \lambda\right)$ is placed into the existing model to create the DEA-VRS model. When the $I 1^{\prime} \lambda \leq 1$ it is the sign of farm is under increasing returns to scale which suggest the DMU to increase the scale or production to achieve efficiency. While $I 1^{\prime} \lambda \geq 1$ implies a decreasing returns to scale of farm. Under this circumstance, the efficiency only can be gained by reducing the scale of production. Hence, this model also can be employed to calculate the nature of efficiency. The formulation is as follows:

Increasing Returns to Scale (IRS):

\begin{tabular}{ll} 
Min $\theta, \lambda$ & \multicolumn{1}{c}{$: \vartheta$} \\
Subject to & $-y_{i}+y \lambda \geq 0$ \\
& $\vartheta x_{i}-x \lambda \geq 0$ \\
& $I 1^{\prime} \lambda \leq 1$ \\
& $\lambda \geq 0$
\end{tabular}

Decreasing returns to Scale (DRS):

$\begin{array}{lc}\text { Min } \theta, \lambda & : \theta \\ \text { Subject to } & -y_{i}+Y \lambda \geq 0, \\ & \vartheta x_{i}-X \lambda \quad \geq 0, \\ & I 1^{\prime} \lambda \geq 1 \\ & \lambda \geq 0\end{array}$

$$
\begin{aligned}
& \text { where; } \quad \begin{array}{l}
\quad y=\text { Quantity of yield (output) } \\
x=\text { Resource or input } \\
i=1, \ldots . ., \mathrm{n}
\end{array}
\end{aligned}
$$

\section{RESULT \& DISCUSSION}

\section{Overall Efficiency}

Table 1 shows the results of technical efficiency of pineapple farmers as classified. The scores ranging from $0-100 \%$ show that the estimation of the CRS and VRS model for farmers is more than 0.50 . No farmers work below 0.50 for both models. Most of the smallholders work at TE within 0.800 to 0.899 for CRS model and within 0.700 to 0.799 for the VRS model. It can be conclude that the pineapple smallholders were not achieving maximum level of output from the given level of inputs. The farmers still can improve their efficiency to get the score of $100 \%$. Also, it was indicated that they were not efficiently utilizing their production resources. This implies that if farm households were to be fully efficient they will achieve a cost savings of $22 \%$ for the CRS model while $17 \%$ when the VRS technology is assumed. The average technical efficiencies of the farmers achieved were 0.78 for CRS model and 0.83 for VRS model respectively indicating ample opportunity for farmers to increase their productivity. 
INTERNATIONAL JOURNAL OF ACADEMIC RESEARCH IN BUSINESS AND SOCIAL SCIENCES Vol. 9, No. 3, March, 2019, E-ISSN: 222 2-6990 @ 2019 HRMARS

Table 1: Frequency distributions of technical efficiency scores obtained with the DEA model

\begin{tabular}{|l|l|l|l|}
\hline Efficiency Score & CRS & VRS & SE \\
\hline$<0.500$ & $0(0)$ & $0(0)$ & 0 \\
\hline $0.500-0.599$ & $12(14)$ & $4(4)$ & 0 \\
\hline $0.600-0.699$ & $11(12)$ & $6(7)$ & 0 \\
\hline $0.700-0.799$ & $21(24)$ & $26(30)$ & $4(4)$ \\
\hline $0.800-0.899$ & $24(27)$ & $22(25)$ & $16(18)$ \\
\hline $0.900-0.999$ & $16(18)$ & $22(25)$ & $49(56)$ \\
\hline 1.000 & $4(5)$ & $8(9)$ & $19(22)$ \\
\hline Mean & 0.78 & 0.83 & 0.94 \\
\hline Standard Deviation & 0.13785 & 0.12294 & 0.0708 \\
\hline Minimum & 0.5 & 0.506 & 0.74 \\
\hline Maximum & 1 & 1 & 1 \\
\hline
\end{tabular}

The result indicated that the efficiency scores varied substantially across farms and there is a potential to increase output gains without increasing input use. The moderate level of technical efficiency scores among the farmers implies the existence of random errors and managerial inefficiency. The VRS technical efficiency is used to measure the relative decline in output that is not a result of the constant return to scale. The scores of technical efficiency in CRS and VRS are to determine whether the farmers are operating at increasing return to scale (RTS) or decreasing RTS. If the score of technical efficiency at VRS is larger than CRS, this means that the farmers are increasing their scale of returns.

Meanwhile, scale efficiency measures the relative loss of output due to the constant's returns to scale represented by the value of one or close to one. According to the theory, increasing returns to scale suggests that the increase of output is higher than inputs. In contrast, the diminishing return to scale indicates that the increase of output is less than the increase in inputs (Nor Diana et al., 2013). When the Scale Efficiency was equal to one (or $100 \%$ ), the scale of production was matched with the inputs and the output. Thus, the adjustment of inputs level and output was not necessary. In implementing the DEA, scale of production for the farmers who achieved $100 \%$ of SE implies that their productions were at the optimal size for their particular input-output combination. For those that achieved below that $100 \%$, it shows that they are yet to achieve the optimal production scale in their cultivation activity. The average scale efficiency is about $89 \%$. This implies that the observed farms can further increase their output by about $11 \%$ if they adopt an optimal scale of production. Meanwhile, as for the remaining $78 \%$ of farmers who achieved SE less than $100 \%$, this result would be indicators to them to modify their combination of inputs in order to achieve the optimal production scale. 
INTERNATIONAL JOURNAL OF ACADEMIC RESEARCH IN BUSINESS AND SOCIAL SCIENCES

Vol. 9, No. 3, March, 2019, E-ISSN: 222 2-6990 @ 2019 HRMARS

Table 2. Efficiency of pineapple production based on the scale of production among pineapple smallholders at Johor

\begin{tabular}{|l|l|l|}
\hline Return to Scale (RTS) & Freq. & \% \\
\hline IRS (sub-optimal) & 23 & 26 \\
\hline CRS (optimal) & 20 & 23 \\
\hline DRS (supra-optimal) & 45 & 51 \\
\hline
\end{tabular}

It also important to understand the distribution of scale of the farms in the three regions of production frontier namely; increasing return to scale, decreasing return to scale and constant return to scale. In Table 2, it could be observed that about $26 \%$ of the farmers were found operating in the region of increasing return to scale. Increasing returns to scale (IRS) suggests that the increase of output is higher than the percentage of the input increased. In contrast, the diminishing return to scale indicates that the increase of output is less than the increase in inputs (Nor Diana et al., 2013). Since they are operating below the optimum scale, the farmers in this region should decrease their production cost in order to increase their production scale. The majority of the farmers which is about $51 \%$ of them were found operating in the region of decreasing return to scale. Therefore, in order to enhance the technical efficiency, the farmers should reduce their production volume. As the farmers in this region were operating above the optimum scale of production scale, this region was also known as supra-optimal. Next, there are about $23 \%$ of farmers who operated at the region of constant return to scale. As they have already achieved optimal scale of productions, they did not need to alter anything.

Technical Efficiency for the Variables

To further analyse which variable that are significant to TE, the TE value for selected variables were calculated and compared within each class. The Variable Return to Scale (VRS) was assumed for this technical efficiency measurement. One way ANOVA analysis was used to see if there is any significance difference among the various variable groups or classes and to see which class are the most technically efficient within the grouped data. 
INTERNATIONAL JOURNAL OF ACADEMIC RESEARCH IN BUSINESS AND SOCIAL SCIENCES

Vol. 9, No. 3, March, 2019, E-ISSN: 2222-6990 @ 2019 HRMARS

Table 3: Technical Efficiency for the Each Variable

\begin{tabular}{|c|c|c|c|c|}
\hline Variable & Class & Mean TE & $\mathbf{F}$ & Sig \\
\hline \multirow{5}{*}{ Age Group (years) } & $21-30$ & 0.8862 & \multirow{5}{*}{49.87} & \multirow{5}{*}{.000} \\
\hline & $31-40$ & 0.7364 & & \\
\hline & $41-50$ & 0.5455 & & \\
\hline & $51-60$ & 0.4397 & & \\
\hline & $61-70$ & 0.4329 & & \\
\hline \multirow{5}{*}{ Farming Experience (years) } & $1-10$ & 0.6381 & \multirow{5}{*}{2.33} & \multirow{5}{*}{0.063} \\
\hline & $11-20$ & 0.5068 & & \\
\hline & $21-30$ & 0.5386 & & \\
\hline & $31-40$ & 0.5535 & & \\
\hline & $41-50$ & 0.5858 & & \\
\hline \multirow{5}{*}{ Education Level } & No Schooling & 0.55 & \multirow{5}{*}{23.96} & \multirow{5}{*}{.000} \\
\hline & Adult Education & 0.55 & & \\
\hline & Primary Education & 0.65 & & \\
\hline & Secondary Education & 0.72 & & \\
\hline & Tertiary Education & 0.87 & & \\
\hline \multirow{7}{*}{ Land Size (hectare) } & $\leq 1.0$ & 0.38 & \multirow{7}{*}{37.88} & \multirow{7}{*}{.000} \\
\hline & $1.01-4.00$ & 0.47 & & \\
\hline & $4.01-8.00$ & 0.63 & & \\
\hline & $8.01-12.00$ & 0.65 & & \\
\hline & $12.01-16.00$ & 0.73 & & \\
\hline & $16.01-20.00$ & 0.79 & & \\
\hline & $\geq 20.01$ & 0.82 & & \\
\hline \multirow{5}{*}{$\begin{array}{c}\text { Labor Utilization (Man-days/ } \\
\text { hectare/ cycle) }\end{array}$} & $\leq 30$ & 0.57 & \multirow{5}{*}{14.39} & \multirow{5}{*}{.000} \\
\hline & $31-60$ & 0.8 & & \\
\hline & $61-90$ & 0.68 & & \\
\hline & $91-120$ & 0.45 & & \\
\hline & $\geq 121$ & 0.22 & & \\
\hline \multirow{7}{*}{ Seeds Density (per hectare) } & $\leq 20,000$ & 0.324 & \multirow{7}{*}{5.535} & \multirow{7}{*}{.000} \\
\hline & $20,001-30,000$ & 0.4197 & & \\
\hline & $30,001-40,000$ & 0.5775 & & \\
\hline & $40,001-50,000$ & 0.5858 & & \\
\hline & $50,001-60,000$ & 0.6203 & & \\
\hline & $60,001-70,000$ & 0.736 & & \\
\hline & $\geq 70,001$ & 0.7901 & & \\
\hline \multirow{6}{*}{$\begin{array}{c}\text { Chemical Application } \\
\text { (L/hectare) }\end{array}$} & $\leq 50$ & 0.4976 & \multirow{6}{*}{14.29} & \multirow{6}{*}{.000} \\
\hline & $51-100$ & 0.7223 & & \\
\hline & $101-150$ & 0.5822 & & \\
\hline & $151-200$ & 0.511 & & \\
\hline & $201-250$ & 0.468 & & \\
\hline & $\geq 251$ & 0.347 & & \\
\hline \multirow{7}{*}{$\begin{array}{l}\text { Fertilizer Application } \\
\text { (kg/hectare) }\end{array}$} & $\leq 1,000$ & 0.2811 & \multirow{7}{*}{2.818} & \\
\hline & $1,001-2,000$ & 0.3724 & & \\
\hline & $2,001-3,000$ & 0.4503 & & \\
\hline & $3,001-4,000$ & 0.441 & & 0.038 \\
\hline & $4,001-5,000$ & 0.6497 & & \\
\hline & $5,001-6,000$ & 0.699 & & \\
\hline & $\geq 6,001$ & 0.7828 & & \\
\hline
\end{tabular}

By referring to the Table 3, the age variable is significant towards TE score, whereas the TE score is higher within the younger group of smallholders. The younger smallholders are more exposed to the latest technology and best management practice compared to the elderly. The same scenario was 
reported by Asem (2013) at Ghana. However, this result contradicted with Nor Diana et al. (2013) findings whereby they found that the age factor is not significantly related to the technical efficiency. The farmer's experience did not affect their technical efficiency level as the mean TE recorded did not have any significant difference across the groups. Thus, there is no significant difference in the technical efficiency measured across the different years of planting experience. In this study, the farmer's experience shows no significant relationship with the technical efficiency. The findings are consistent with the results by Nor Diana et al. (2013) where they found out that farming experience is not significantly related to the technical efficiency. This means that being an experienced farmer is not good enough to achieve the higher level of efficiency. For education level variable, different level of education received by the farmers did affect their TE level.

As shown in Table 3, the technical efficiency increased as the education level increases. Literate farmers can manage their farm record better as they can read and write. Some of the farmers cannot even perform any readings and writing activity. Thus, it will affect their ability to record the farm expenses as well as the profitability level, therefore, it can be concluded that the level of education can affect the smallholder's efficiency level. The result of the TE score for land size variable is significant. From the result obtained, it can be concluded that the technical efficiency score is increasing as the land size increases. The bigger the land size, the higher the technical efficiency scores. Farmers that work in a bigger farm have a higher technical efficiency score and this result is consistent with the result by Adegbite et al. (2015), Akhilomen et al. (2015), and Nor Diana et al. (2013).

The next variable discussed is labour working hours for each hectare. This variable is a sum of both family labour and paid labour. The result shows that the labour technical efficiency is higher for the labour utilized between 31 man-days to 60 man-days. The suggested labour utilization by Malaysia Pineapple Industry Board is 272 hours or 55 man-days. Thus, it can be concluded that most labour are technically efficient when they work between 31 man-days to 60 man-days. Labour variable is significant towards smallholder's technical efficiency level. Adegbite et al. (2015) and Akhilomen et al.(2015) also reported the same findings at Nigeria, while Asem (2013) reporting similar situations at Ghana.

As for the plant density, which was measured by seeds per hectare, the average seeds planted by the sample farmers is 35,617 , which is slightly lower than the recommended density that was suggested by Malaysia Pineapple Industry Board (MPIB). MPIB suggests planting 37,500 seeds for each hectare. The minimum seeds density reported were 12,500 while the maximum is 75,000 . There is a big gap between the minimum and the maximum seeds planted in each hectare. This is due to the farmer's preferences whereby some of them claimed that they prefer to plant the seeds less than the density suggested by the MPIB. For them, it is much easier to do the technical activity in manual weeding rather than leaving more spaces between each planted row. For those farmers planted more than what MPIB had suggested, they are under the groups of smallholders that undergo a 'High Impact' project whereby they try to double up the density of the seeds plant, thus it can lead to a higher number of outputs. Most of the smallholders that were assigned to this project are young farmers 
that are braver to explore and have a better educational background. Based on Table 3, it can be concluded that the seed density variable is significant to the smallholder's technical efficiency. This result is aligned with Adegbite et al. (2015) and Asem (2013).

For some crops, fertilizer and chemical are fixed variables. But, for this study, the volume of the fertilizer and chemical applied is varied depending on the smallholder's situation and needs. The higher the density of the seeds planted, the higher the amount of the fertilizer applied. The fertilizer is significant towards the smallholder's technical efficiency. The technical efficiency readings increased concurrently with the increased of the fertilizer applied. In terms of the chemical utilization, the farmer needs to repeat the weedicide activity until the weeds are totally gone (MPIB, 2014). Therefore, the amount of the chemical used by each hectare is depending on the amount the farmer needs to repeat the process. It can be concluded that there is a significant difference in the efficiency level of the six classes of the chemicals applied. From the calculated mean of the technical efficiency, the results show that the optimum value of the chemical applied is between 51 litres to 100 litres per hectare, whereby the technical efficiency calculated are lower when the chemical level applied is higher. However, the chemical variable still shows a significant impact toward smallholder's technical efficiency. This finding is similar to Asem (2013).

\section{CONCLUSION}

The findings of this study brought to fore a number of issues that are needed to be addressed. Therefore, there is a need to recommend to the policy maker to do some improvement to the pineapple production especially at the smallholder's side. The technical efficiency of the pineapple smallholders at Johor is low indicating that there is technical inefficiency problem. As revealed, the technical inefficiency factor comes from the improper use of variables. It is in line with the findings that show pineapple production in the study area is under decreasing returns to scale. This circumstance suggests the farmers to reduce the cost of production in order to increase the output. Hence, the function of extension agent in the research area must be revived. Continuous attachment and advice to the smallholders will help them to make the right technical decision and guide the smallholders to become a more efficient farmer.

It is important to expose the smallholders with the knowledge and new set of technology. The skills and knowledge of the farmers in the pineapple farming can be expanded by providing formal or informal education programmes to regain the smallholder's abilities in processing new information regarding the modern agricultural technology. The younger smallholders have a higher technical efficiency because they are more literate and exposed to the new technology. With a proper guidance and knowledge, the smallholders can increase their productivity by focusing on the applications of the variables. Apart from that, farmers centred training or workshop must be implemented to expose the small-scale producers in the resource use efficiency and managerial efficiency. 
INTERNATIONAL JOURNAL OF ACADEMIC RESEARCH IN BUSINESS AND SOCIAL SCIENCES

Vol. 9, No. 3, March, 2019, E-ISSN: 222 2-6990 @ 2019 HRMARS

\section{REFERENCES}

Akhilomen, L. O., Bivan, G. M., Rahman, S. A. (2015). Economic efficiency analysis of pineapple production in Edo State, Nigeria: A stochastic frontier production approach. Ahmadu Bello University: Nigeria.

Asem, F. (2013). Technical efficiency of smallholder horticultural farmers in Ghana. In the Proceedings of the 2013 Agricultural Development within the Rural-Urban Continuum

Charnes, A., Banker, R. D. and Cooper, W.W. (1984). Some models for estimating technical and scale in- efficiencies in data envelopment analysis. Management Science, 309:78-92.

Farrell, M.J. (1957). The Measurement of productive efficiency. Journal of the Royal Statistical Society (A, general), 120: 253-281.

Malaysian Pineapple Industry Board (MPIB), 2014. The manual for pineapple cultivation activity, Johor, Malaysia

Malaysian Pineapple Industry Board (MPIB), 2015. Malaysia pineapple industry survey for 2014, Johor, Malaysia.

Ministry of Agriculture and Agro-Based Industry (MOA), 2015. Total Pineapple Cultivation Area and its Production by State. Retrieved December 01, 2015, from data.gov.my/view.php?view=298.

Nik Ismail, N. M. Y., Sabrina, S., and Irfan, S. (2010). Malaysian pineapple industry research study: domestic market and competitiveness. Qi Consultants Sdn. Bhd., Johor, Malaysia.

Nor Diana, M. I., Chamhuri, S. and Basri, T. (2013). Determinants of technical efficiency on pineapple farming. American Journal of Applied Sciences, 10:426-432.

Ogundari, K. and Ojo, S.O. (2007). An examination of technical, economic and allocative efficiency of small farms: The case study of cassava farmers in Osun State of Nigeria. Bulgarian Journal of Agricultural Science, National Centre for Agrarian Sciences,13: 185-195. 